\title{
RESPONSES OF THE RODLET CELLS TO METACERCARIAL INFECTIONS IN OREOCHROMIS NILOTICUS
}

\author{
WALAA F.A. EMEISH ${ }^{1}$, MARWA M. FAWAZ ${ }^{2}$ and ZEINAB AL-AMGAD ${ }^{3}$ \\ ${ }^{1}$ Fish Diseases and Management, Department of Fish Diseases, Faculty of Veterinary Medicine, South Valley University, \\ Qena, Egypt. \\ ${ }^{2}$ Department of Parasitology, Faculty of Veterinary Medicine, South Valley University, Qena, Egypt. \\ ${ }^{3}$ Veterinary National Service, PhD in Veterinary Pathology and Clinical Pathology, Faculty of Veterinary Medicine, South \\ Valley University, Qena, Egypt.
}

Received: 24 June 2018; Accepted: 17 January 2019

\begin{abstract}
In this report, we describe the responses of Rodlet cells (RCs) of Nile Tilapia, Oreochromis niloticus, with other inflammatory indicators to infections by encysted metacercariae trematodes. RCs are specialized cells of the non-specific immune system of some species of teleosts fish. Sixty eight out of 100 examined fish specimens were found to be naturally infected by the encysted metacercariae in different parts of the body. Digenean metacercariae infection caused significant increase in serum total protein and albumin level concentrations than in uninfected wild caught fish, a possible indication of an infection or inflammatory host response. Significant increase in eosinophils percent revealed parasitic infections. A variable number of RCs were observed in gills and liver tissues of infected fish, with a higher frequency, while couldn't be found in uninfected tissues. Results propose that RCs represent an inflammatory cell type that is closely linked to other piscine inflammatory cells in respond to the presence of parasites on epithelial surfaces.
\end{abstract}

Key words: Rodlet cells, Oreochromis niloticus, encysted metacercariae, biochemical parameters.

\section{INTRODUCTION}

Recently, RCs of the teleosts have drawn a lot of attention as fish inflammatory cells that are involved in the non-specific immune response against parasitic infections (Reite, 2005). Rodlet cells have been identified as fish blood cells (Weinreb and Bilstad, 1955) and formerly were considered as regulatory elements related to special functions such as transportation of ions (Morrison and Odense, 1978), osmoregulatory mechanisms (Mattey et al., 1979), transport units of genetic material (Viehberger and Bielek, 1982), secretory cells (Leino, 2002), and non-specific immune cells (Dezfuli et al., 1998; Dezfuli et al., 2000; Dezfuli et al., 2002; Dezfuli et al., 2003a; Dezfuli et al., 2003b).

The influence of parasites on fish population is widely recorded (Abdel-Ghaffar et al., 2013). Nile tilapia, Oreochromis niloticus, is a freshwater fish

Corresponding author: Walaa Fathy Aly Emeish

E-mail address: walaavet2002@yahoo.com

Present address: Lecturer of fish Diseases, Department of fish Diseases, Faculty of Veterinary Medicine, South Valley University, Qena 83523, Egypt. belongs to the Family Cichlidae. It is widely distributed and native to Africa and has been used in aquaculture in different parts of the world because of its good characteristics such as rapid reproduction and growth rates (Nandlal and Pickering, 2004).

Digenetic trematodes constitute the largest group of all internal metazoan parasites gathers about more than 2,500 nominal genera, and in general its life cycle includes three hosts, two intermediate and one definitive. Metacercariae are the infective larvae found in the fish that act as the second intermediate hosts. In fish most of detected metacercariae were with unique morphologies so they are morphologically distinguished species by species (Sohn, 2009; 2013).

Blood examination have been applied as physiological indicators to changing external environment (Caruso et al., 2005) and used to evaluate normal health status and to diagnose diseases caused by various factors, like parasitic infections, and others (Fedato et al., 2010). Hence, any alterations associated with Haematobiochemical parameters due to various parasites establish a data base, which could be used in diagnosis of diseases and in guiding the inquiry of 
the treatment or preventive measures (Yaji and Auta, 2007).

The aim of the present study was to describe the response of RCs in gill tissues to infection with a range of parasitic genera including representatives from the Digenea trematodes, metacercariae in wild Nile tilapia, O. niloticus collected from the River Nile in Qena Province. Moreover, the potential effects of occurrence of these parasites on selected inflammatory and biochemical indicators and histopathological finding in gills were also studied.

\section{MATERIALS AND METHODS}

\section{Fish samples:}

Nile tilapia, O. niloticus $(\mathrm{n}=100)$ with an average body weight of $50 \pm 10$ grams were collected alive from two different River Nile Branches at Qena Governorate, South Egypt by the aid of fisherman and then transported alive to the aquatic laboratory at Faculty of Veterinary Medicine, South Valley University, Qena, Egypt, where they were subjected to parasitological, biochemical and histopathological examinations.

\section{Blood samples:}

Fresh blood samples were collected without anticoagulant from 12 digenetic trematodes metacercariae infected and 12 non-infected wild caught fish from the caudal peduncle according to (Lied et al., 1975). Blood films were prepared, air dried, methanol fixed and stained with diluted Giemsa stain for differential leucocytic count (DLC). Serum was obtained by allowing blood to clot for $30 \mathrm{~min}-45 \mathrm{~min}$ and then centrifuged at $3000 \mathrm{rpm}$ for 15 minutes and non-hemolysed Serum samples were transferred to separate Eppendorf tubes and preserved at $-80^{\circ} \mathrm{C}$ until use for biochemical analysis.

\section{Clinical and postmortem examinations:}

The infected fish were subjected to clinical as well as post mortem examinations according to the methods described by Austin and Austin (2016) for detection of any external or internal abnormalities.

\section{Parasitological examination:}

External and internal examinations were done for detection of metacercaria cysts, by naked eye and / or by using of magnification lenses, smears on glass slides were made from scrapings of the gills, skin and fins for examination of smaller metazoan (Ayanda, 2009). Fish gills were dissected out and each gill filament and arch was examined for the presence of digenean cysts. The fishes were dissected to expose the viscera. The visceral cavities and organs were examined for metacercarial cysts according to (Syme, 1966). Microscopical examination made by put a very small piece of musculature of each sample from different regions and depths, from right and left sides, mixed with few drops of saline solution and compressed between two glass slides and examined microscopically according to the method reported by (Morishita et al., 1965).

\section{Biochemical analysis:}

Samples were thawed at room temperature and the following analysis were made: levels of serum total protein and albumin were measured using spectrophotometry and "Total Protein" and “Albumin" kits (Spectrum, Egyptian Company for Biotechnology, Obour City, Cairo, Egypt) according to manufacturer's recommendation. Subtracting the concentration of albumin from that of the total protein was done to obtain blood serum globulin (Coles, 1986).

\section{Histopathological examination:}

Infected fish with Digenean as well as non-infected fish were subjected to histopathological examination in order to compare and specify the pathological lesions observed if it attributed to Digenean infection or other environmental, nutritional and other infections. Samples from gills and liver were collected, fixed in 10\% neutral buffered formalin, washed in running water and dehydrated in different grades of concentrated alcohol, cleared in xylene and embedded in paraffin wax. Paraffin sections of 4-5 $\mu \mathrm{m}$ thickness were obtained and stained by with Harries hematoxylin and eosin for microscopical examinations according to (Culling et al., 1985). Other sections subjected to special stain using Periodic Acid Schiff (PAS) according to (Mc Manus, 1948). Then covered and examined microscopically.

\section{Statistical analysis:}

Data are presented as mean \pm standard error. A twoway analysis of variance (ANOVA) were done to calculate any significant differences between infected and uninfected groups using Graph Pad prism 6, version 6.01, significance was set at $95 \%$.

\section{RESULTS}

In the present study, digenean metacercariae were detected in $68 \%$ fish species, but their all species names could not be determined, while $32 \%$ were uninfected. The encysted metacercariae could be recorded mainly in gills tissue, branchiostegal muscle, also in pericardial muscle, chin region, branchiostegal membrane and in internal organs as muscle and kidney tissue (Figure 1). 


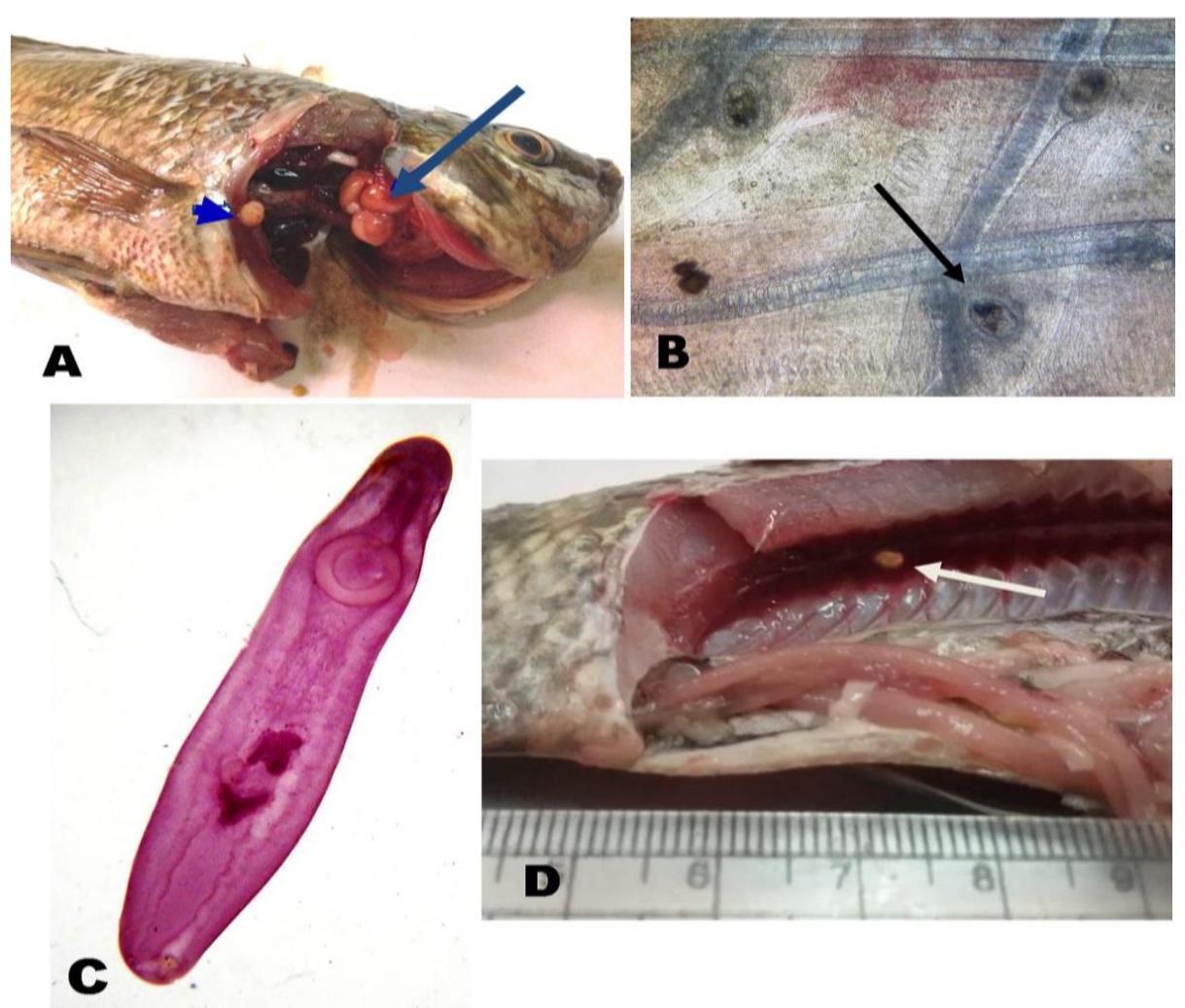

Figure 1 (A): Encysted metacercaria (Clinostomum sp.) at gills tissue \{Arrow $\}$ and branchiostegal membrane \{Arrow head\} (Camera digital).

Figure 1 (B): Unidentified Encysted metacercaria at gills tissue (Microscopically X10).

Figure 1 (C): Clinostomum sp. stained with alum carmine stain (X4).

Figure 1 (D): Encysted metacercaria (Clinostomum sp.) at kidney tissue (Camera digital).

The results of the biochemical indices determined for both infected and uninfected species of $O$. niloticus are presented in (Table 1). The results indicated vividly that serum total protein and albumin levels concentration were higher in the infected than in the uninfected fishes for studied species. Statistical analysis revealed significant differences between the serum parameters of the infected and uninfected species. However, globulin ratio was lower in the infected than in the uninfected fishes. Statistical analysis revealed insignificant differences.

Results of DLC showed that, the esoinophils and monocytes percent were found to be significantly higher in the infected fishes than in the uninfected ones. While neutrophils percent, were significantly lower in the infected fishes than in the uninfected ones. Results presented in Table 1.

Table 1: Biochemical and inflammatory alterations in Nile Tilapia due to metacercariae infections.

\begin{tabular}{|c|c|c|}
\hline Parameter & $\begin{array}{l}\text { Non infected } \\
\text { (control) } \\
\mathrm{n}=12\end{array}$ & $\begin{array}{c}\text { Infected } \\
n=12\end{array}$ \\
\hline Total protein $\mathrm{g} / \mathrm{dl}$ & $3.7 \pm 0.18^{b}$ & $4.5 \pm 0.34^{\mathrm{a}}$ \\
\hline Albumin g/dl & $1.5 \pm 0.1^{\mathrm{b}}$ & $1.9 \pm 0.16^{\mathrm{a}}$ \\
\hline Globulin g/dl & $2.2 \pm 0.1^{\mathrm{a}}$ & $2.6 \pm 0.3^{\mathrm{a}}$ \\
\hline Lymphocyte \% & $38.75 \pm 1.02^{\mathrm{a}}$ & $37.08 \pm 1.1^{\mathrm{a}}$ \\
\hline Monocyte $\%$ & $32.92 \pm 1.5^{\mathrm{b}}$ & $36.08 \pm 0.8^{\mathrm{a}}$ \\
\hline Neutrophil \% & $16.41 \pm 1.04^{\mathrm{a}}$ & $13.75 \pm 0.7^{b}$ \\
\hline Basophile $\%$ & $8.8 \pm 0.7^{\mathrm{a}}$ & $8.6 \pm 0.5^{\mathrm{a}}$ \\
\hline Eosinophil $\%$ & $3.08 \pm 0.3^{b}$ & $4.4 \pm 0.4^{\mathrm{a}}$ \\
\hline
\end{tabular}


At the normal condition; histological section of gills revealed normal architecture, since RCs couldn't be distinguished in case of absence encysted metacercarial infection (Fig. 2 a-b). The present study involved Nile Tilapia subjected to parasitic infections which appeared among gills tissues inform of variable sized encysted metacercarial infection surrounded by RCs (Fig. 2 c-d). In response to parasitic infection, there were large population of RCs infiltration among interstitial tissues appeared oval shaped with eosinophilic granular cytoplasm and blue peripheral nuclei when stained by Haematoxylin and Eosin (Fig. 2 e-f). Moreover, primary and secondary lamellae exhibited variable number of RCs related to damage tissues (Fig. 2 g). While when stained PAS, RCs appeared deeply stained blue coloration concentrated at the primary and secondary lamellae in associated with damaged gill tissues (Fig. 2 h).
The histological section of gills of control fish free from parasitic manifestation showed normal architecture composed of gill rackers, gill arch, and filaments. Since, gill arch radiates double rows of paired primary lamellae. Each of these primary lamellae has a series of secondary lamellae located perpendicular to the primary lamellae (Fig. 3 a). While, fish that infected with encysted metacercaria were accompanied with remarkable histopathological changes in the gills tissue characterized by pronounced necrosis of the primary and secondary lamellae (Fig. 3 b). On the hand, gill lamellae showed hyperplasia in the epithelial lining led to focal fusion at the tips of the secondary lamellae (Fig. 3 c). Congestion in the central venous sinus of the primary lamellae was observed, in addition to severe destruction and sloughing of the lamellae (Fig. $3 \mathrm{~d}$ ). There was curling and curving of some lamellae, besides shortening of others. Gills arch exhibited interstitial mononuclear cells infiltration mainly lymphocytes.
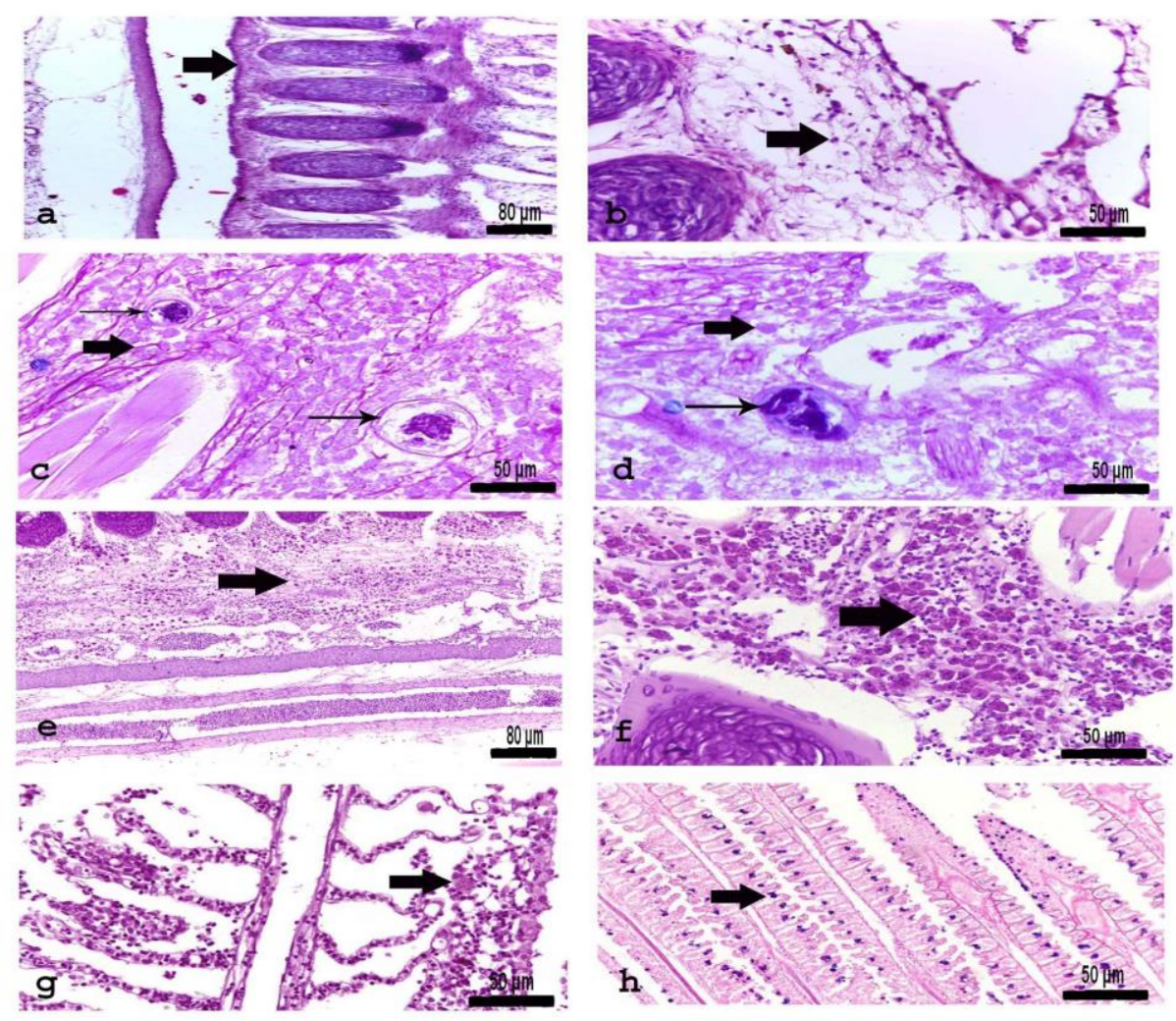

Figure 2 (a-b): Histological section in gill tissues showing normal architecture, besides deprived cystic metacercrial infection and free from rodlet cell infiltration (a). High power of Fig. a, was showing normal architecture with absence of rodlet cell infiltration (b). (H\&E., bar $=50 \& 80 \mu \mathrm{m}$ ).

Figure 2 (c-d): Histological sections in gill tissues showing variable sized encysted metacercarial infection (thin arrows) with rodlet cells infiltration (thick arrows). (PAS, bar $=50 \& 80 \mu \mathrm{m}$ ).

Figure 2 (e-g): Gills associated with encysted metacercarial infection showing extensive rodlet cells infiltration among tissues (e). High power of Fig. e showing oval shaped rodlet cells with eosinophilic granules and blue peripheral nuclei (f). Gills showing rodlet cells infiltration among primary and secondary lamellae with damaged tissues (g). (H\&E., bar $=50 \& 80 \mu \mathrm{m}$ ).

Figure 2 (h): Gills stained with PAS showing deeply blue stained rodlet cells at primary and secondary lamellae (h). (PAS, bar $=50 \mu \mathrm{m})$. 

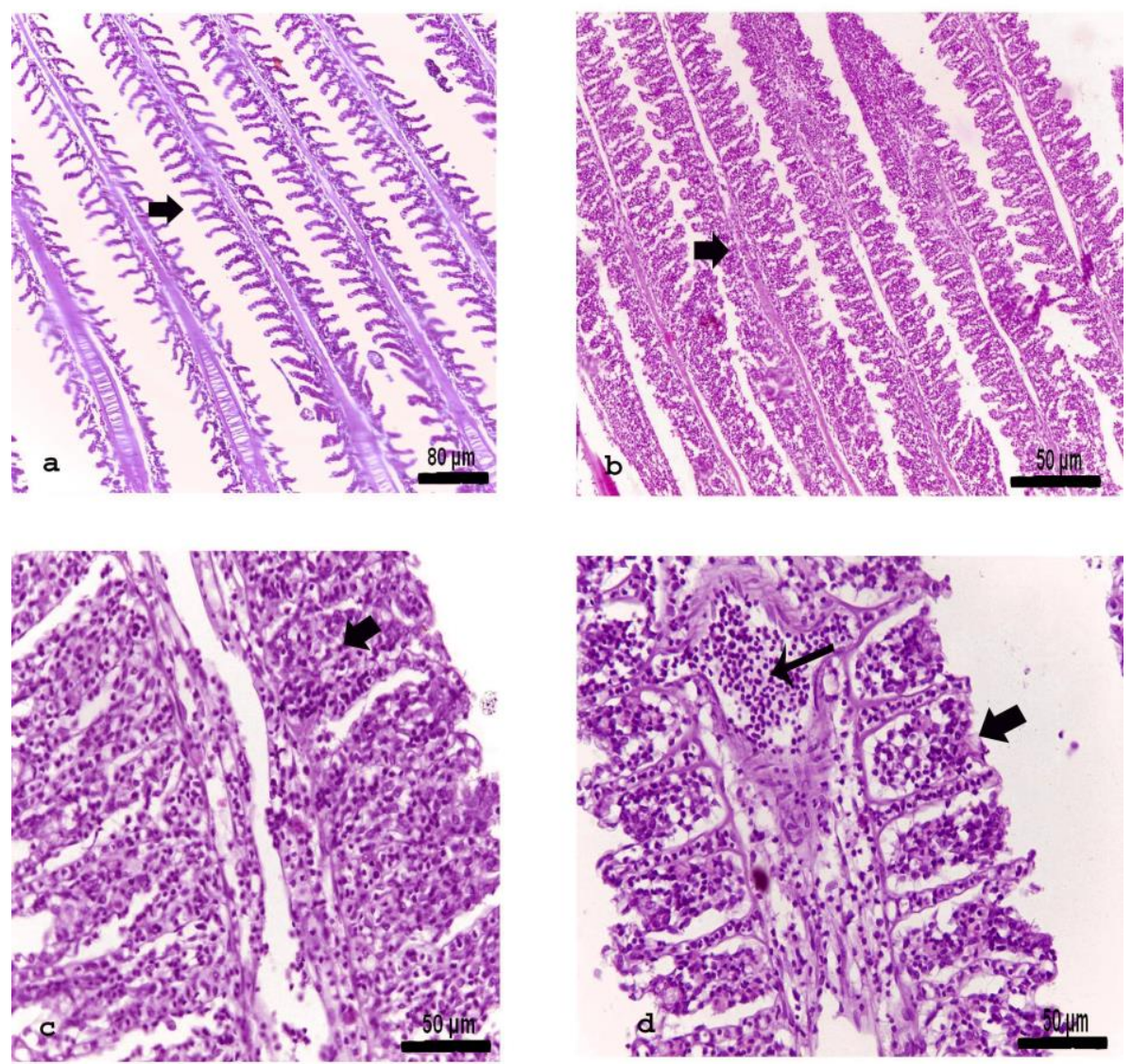

Figure 3 (a): Histological section in gills showing normally arranged primary lamella with a series of secondary lamellae located perpendicular to the primary lamellae (a). (H\&E., bar $=80 \mu \mathrm{m})$

Figure 3 (b-d): Histopathological changes accompanied by encysted metacercarial infection showing pronounced necrosis of the primary and secondary lamellae with curling of some secondary lamellae (b). Gills were showing focal fusion in the tips of the secondary lamellae (c). Gills were showing congestion in the central venous sinus of the primary lamellae, besides severe destruction and sloughing of the primary and secondary lamellae (d). (H\&E., bar $=50 \& 80 \mu \mathrm{m})$

The histological section of liver of the infested fish displayed encysted metacercaria embedded among hepatic tissues (Fig. 4 a-b). The liver when stained with PAS showed large encysted metacercarial infection filled with parasitic eggs and surrounded by dense fibrous capsule (Fig. 4 c-d). Also, liver exhibited extensive rodlet cells infiltration with eosinophilic appearance, since there was rodlet cells infiltration related to hepatopancreas (Fig. 4 e-f). The histological section of the control liver was devoid of encysted metacercarial infection or any parasitic cysts, where the hepatic tissue showed normal criteria that composed of branching and anastomosing hepatocytes. Hepatocytes are polygonal with distinctive central nucleus (Fig. 5 a). Liver of the infested fish revealed pronounced histopathological lesions involving hepatic damage and necrosis characterized by small tiny condensed nuclei of the hepatocytes adjacent to central vein (Fig. 5 b-c). Liver showed hyperactivation of kupffer cells among the hepatocytes (Fig. 5 d). Liver showed fatty degenerative changes with fat cells infiltration and mononuclear cells infiltration aggregation mainly lymphocytes (Fig. 5 e). The infested liver revealed proliferation of melanomacrophages. Also, hepatopancreatic area suffered from cytoplasmic vacuolation with inflammatory cells infiltration (Fig. 5 f). There was hemorrhagic inflammation manifested by erythrocytes and lymphocytes cells infiltration (Fig. $5 \mathrm{~g}$ ). The blood vessels showed thrombotic congestion of the central vein characterized by presence of the fibrinous exudate with lymphocytes and stagnant erythrocytes infiltration attached to the vessels wall (Fig. $5 \mathrm{~h}$ ). 

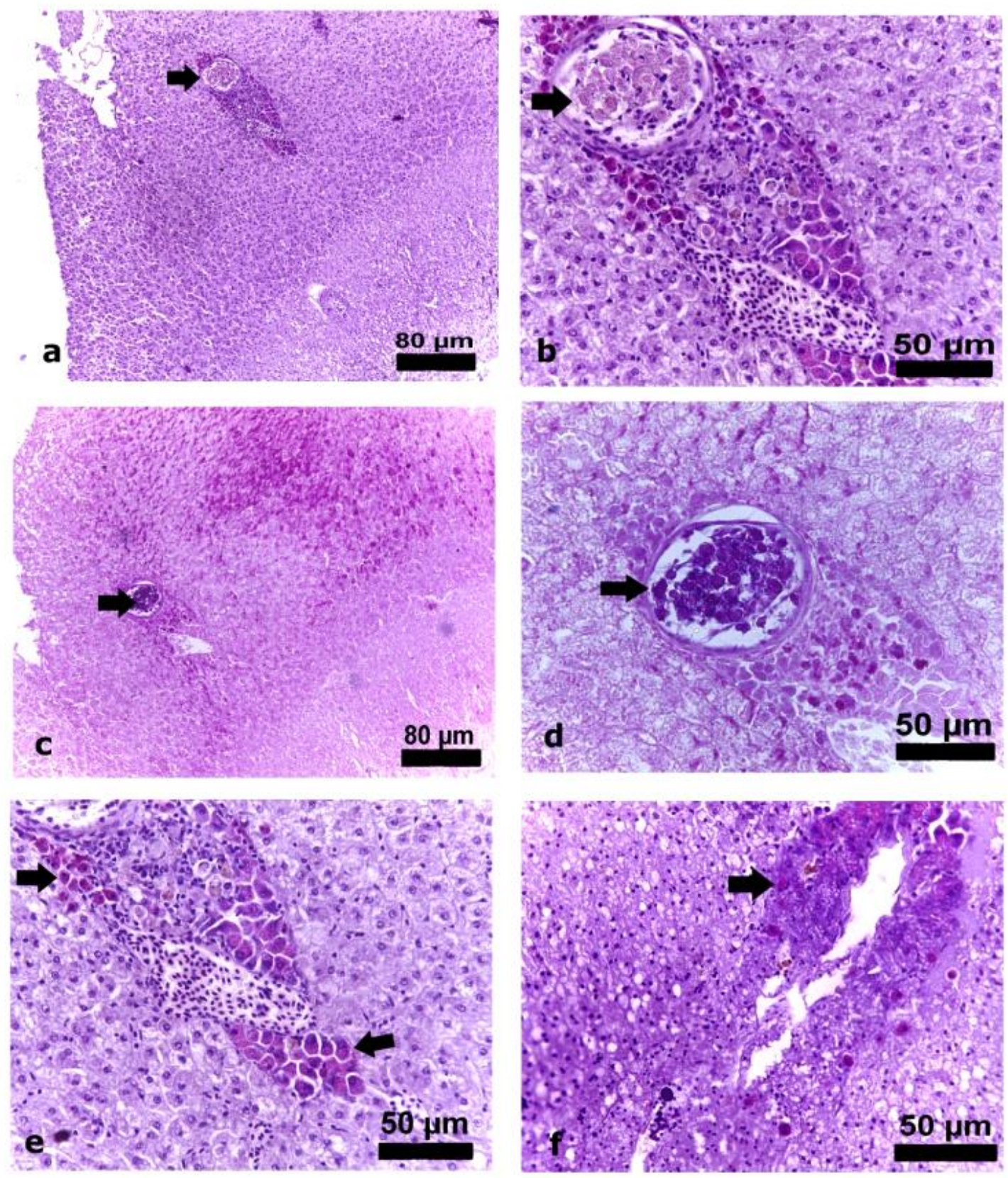

Figure 4 (a-b): Histological section in liver showing encysted metacercarial infection embedded among hepatic tissues (a). High power of Fig. a showing encysted metacercarial infection embedded among hepatic tissues (b). (H\&E., bar $=50 \& 80 \mu \mathrm{m})$.

Figure 4 (c-d): Liver with especial stain showing encysted metacercarial infection embedded among hepatic tissues (c). High power of Fig. c showing encysted metacercarial infection embedded among hepatic tissues $(\mathrm{d})$. (PAS, bar= $50 \& 80 \mu \mathrm{m})$.

Figure 4 (e-f): Liver showing extensive rodlet cells infiltration with eosinophilic appearance (e). Liver showing rodlet cells infiltration related to hepatopancreas (f). (H\&E., bar= $50 \mu \mathrm{m})$. 

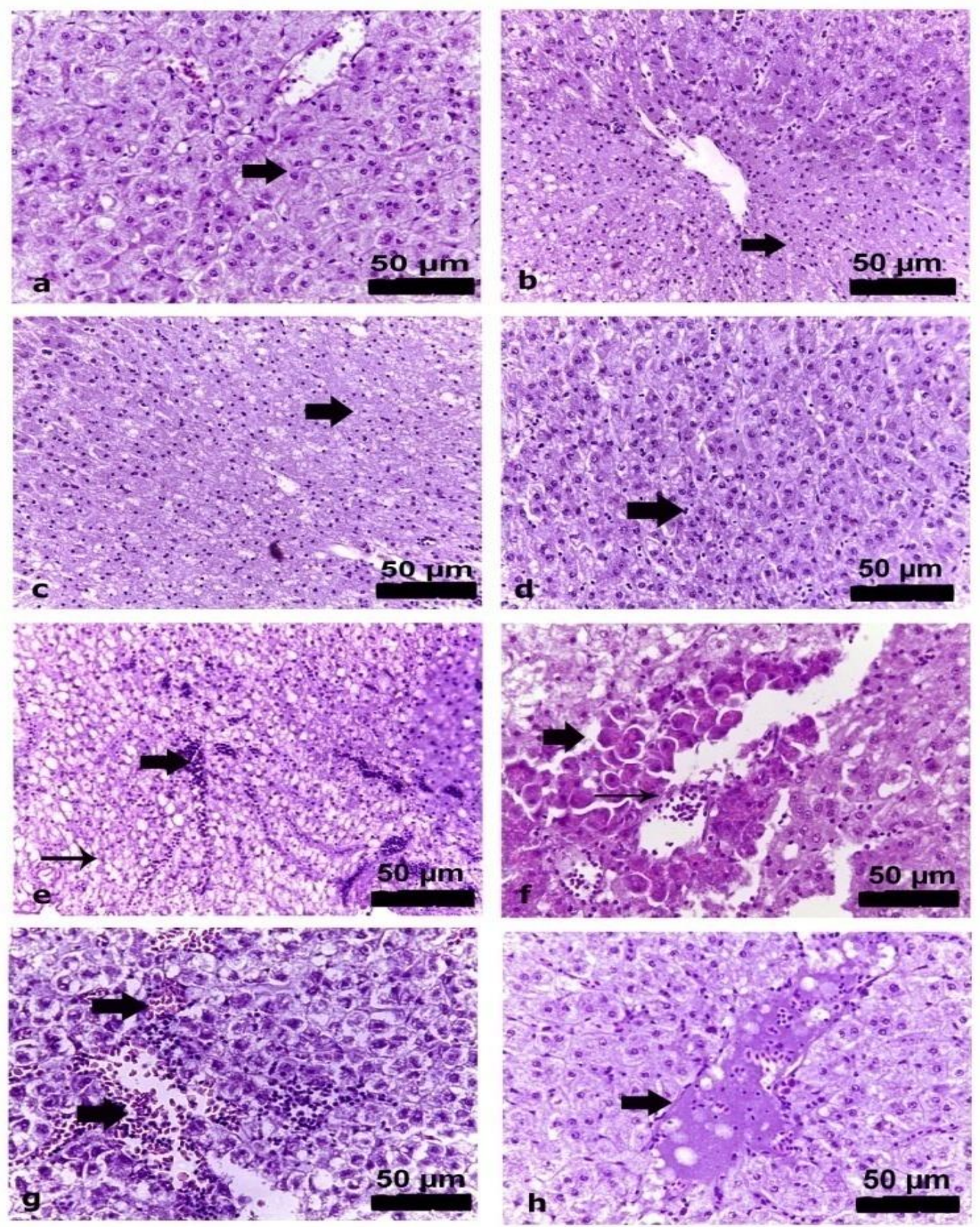

Figure 5 (a): Histological section in control liver showing normal arrangement of the hepatocytes with polygonal shapes (b). (H\&E., bar= $50 \mu \mathrm{m}$ ).

Figure 5 (b-h): Histopathological changes of the infested liver showing hepatic necrosis adjacent to central vein (b). Liver showing hepatocytes necrosis with tiny condensed nucleus (c). Liver showing hyperactivation of kupffer cells (d). Liver showing fatty infiltration with lymphocytes aggregation (e). Liver showing hepatopancreatic vacuolation with inflammatory cells infiltration (f). Liver showing extravasation of red and white blood cells among hepatocytes (g). Liver showing thrombotic congestion of the central vein (h). (H\&E., bar $=50 \mu \mathrm{m}$ )

\section{DISCUSSION}

Parasites extensively affect immunity of fish which modulated by pathogen recognizing receptors that can reduce the parasite load (Alvarez-Pellitero, 2008). The cellular involvement in the inflammatory response in teleost fish could be having two phases, beginning with neutrophils inflow and later by monocytes and macrophages (Reite and Evensen, 2006). Furthermore, another inflammatory cellular type is the enigmatic rodlet cells, which located in the epithelial tissues and exclusive to fish species, with a higher variability in their distribution and abundance (Alvarez-Pellitero, 2008). Abd-Elhafeez 
and Soliman (2016) concluded that, RCs originated from the stroma of the olfactory organ.

There are arguments over the kind of rodlet cells, but mainly there are three suggestions: one supports that the RCs are glandular components of the connected epithelium (Iger and Abraham, 1997; Imagawa et al., 1998); the second distinguish these cells as protozoan parasites of the Sporozoa (Agulleiro et al., 1986). The main alibi that RCs are parasite is that their numbers differ from fish to fish and often they cannot be found in all individuals of the same species (Manera and Dezfuli, 2004). The third view recognizes RCs as a kind of granulocytes, which is based on common features between RCs and white blood cells (Smith et al., 1995a; Smith et al., 1995b) and aggregation of RCs at the site of infection due to metazoan (Dezfuli et al., 1998; Dezfuli et al., 2000; Dezfuli et al., 2003a) and protozoan parasite (Dezfuli et al., 2004). Several studies have reported that RCs are associated with the immune system of fishes (Manera and Dezfuli, 2004; Bielek, 2005; Reite, 2005). In consequence, although the role of RCs in organisms is not completely understood, RCs was considered as biomarkers in inflammation and parasitic infections, with a similar target to eosinophil, epithelioid and mesothelial cells (Iger and Abraham, 1997; Araujo and Borges, 2015). Previous studies have also reported that exposure to adverse environmental conditions and toxic substances lead to increased numbers of RCs in fish (Hawkins, 1984; Manera and Dezfuli, 2004).

This study has reported increase in the number of RCs in gills and liver tissues of fish exposed to parasitic infections than in uninfected fish, and this was associated with stimulation of antibodies in a response to parasitic infection. There is a correlation between the rising number of RCs and fish parasite infections (Dezfuli et al., 1998; Dezfuli et al., 2000; Dezfuli et al., 2003a). Protozoans, myxozoans and helminths, seem to induce the induction of RCs with variability in their abundance and distribution (Manera and Dezfuli, 2004).

Matisz et al. (2010) studied changes of RCs in the optic lobes of fathead minnows exposed to trematode cercariae. Smith et al. (1995b) noted higher numbers of RCs around lesions in the head kidney of Angelfish. A variable number of RCs was observed in gills and kidneys tissues, with a higher frequency in gills compared to the kidneys. RCs were observed in healthy fish and in fish parasitized by a myxosporean of the genus Henneguya (Mendonca et al., 2005). Compromise integrity of the RCs in gills tissues occurred in $O$. niloticus exposed to organophosphate pesticide methyl parathion (Araujo and Borges, 2015).
In addition to the RCs infiltration, there were remarkable histopathological changes encountered in gills of fish infested with encysted metacercaria when compared with non-infested cases in the present study represented by necrosis, focal fusion of gills lamellae, besides congestion of the blood vessels. Aly et al. (2005) displayed that encysted metacercariae of two trematodes (Prohemistomum vivax and Mesostephanus applendiculatus) caused pronounced pathological changes in gills characterized by desquamation of the secondary lamellae, hyperplasia in the epithelium with fusion in their lamellae, besides edema, congestion and mononuclear leukocytic infiltration. Fish parasites are capable of producing proteolytic enzymes responsible for tissue deterioration (Jones et al., 2004; Soror, 2008) and possibly parasite encystations (Martone et al., 1999). The degenerative changes of gills resulted in hypoxia and osmoregulatory failure and consequently death of host. The degree of pathogenicity depends on many factors, such as the species involved, its life cycle and biology, the host species, host age, state of nutrition and host resistance. The degenerative changes could be due to the pressure or toxic products induced by the parasitic cysts (Aly et al., 1995). Yemmen et al. (2011) discussed that the adhesive disc of the parasite lead to decreased respiratory surface and gaseous exchange resulting in hypoxia with lack of oxygen. Encysted metacercariae was associated with destruction of secondary lamellae with loss of the normal gill architecture, similar to (Abdel-Latif, 2007; Reda et al., 2010; Eissa et al., 2011) who recorded congestion of the blood vessels in addition to mononuclear inflammatory cellular infiltration in gills of $O$. niloticus infected with encysted metacercaria. In addition, (Shoaibi Omrani et al., 2010) noted hyperplasia and hypertrophy with fusion of the gill filament of platy fish infested with metacerceria. (Aly et al., 1995) expressed that inflammatory reactions detected in the gills due to the impact of toxic metabolites produced by the larvae with the prolonged irritation of the parasitic cysts.

Pathological lesions of liver showed hepatic necrosis and damage associated with inflammatory reactions were correlated to a direct effect of the parasites through attachment to the wall of the organ leading to compressing cellular death and damage inflammatory reactions (Hossam et al., 2012). Also hepatic damage and atrophy which may be a result of escape of nutrients from the host tissue to the metacercariae caused shrunken hepatocytes (Harris et al., 2005). Sommerville (1982) recorded that marked inflammatory changes and focal hemorrhages followed penetration and early migration of metacercariae. The inflammatory reaction, predominated by infiltrating macrophages, 
is particularly intense around unencysted migrating metacercariae and preceded the eventual enclosure in a fibrous capsule of the encapsulating metacercaria (Yekutiel, 1985). Hyperactivation of kupffer cells among the hepatocytes was detected in response to immune system. Fatty degeneration was noticed with fat infiltration due to the pressure or toxic harmful products released by the parasitic cysts (Aly et al., 1995).

The physiological status of the fish infested by parasites can be diagnosed by blood parameters which act as a reflector of the health of an organism (Joshi et al., 2002) and the normal physiology and nutritional conditions of fish (Chagas and Val, 2003). The total protein and albumin concentrations in fish serum reflect the health of the animal, liver function, metabolic status and stress conditions (Kovyrshina and Rudneva, 2012).

With progress of any infection usually marked changes in the total serum proteins were detected. There may be elevated concentration of the total protein during some stage of the infection. Results of the present study indicated that the blood serum total protein and albumin levels were significantly higher in metacercariae infested fish. In another study on the biochemical parameters of Clarias batrachus infested with trypanosomosis, insignificant higher levels of albumin were reported in infested fish (Kharat and Kothawad, 2012), while Osman et al. (2009) reported low serum albumin levels in $C$. gariepinus with trypanosomosis.

There are many factors responsible for variation in total protein and albumin concentrations in fish serum other than parasite infection, since it has been noted that diet composition, species, stage of life cycle, age, sexual maturation, environmental and health factors (Patriche et al., 2009; 2011; Chukwuma et al., 2010; Kovyrshina and Rudneva, 2012) also affect total protein and albumin levels. The increase in albumin value consequently leads to decrease in globulin, as globulin was obtained by direct subtracting the values of the albumin from those of the total protein. Globulin and total protein levels indirectly give indication about the condition of specific humeral immunity (Stosik et al., 2001; Maqsood et al., 2009). Albumin is considered as an important serum protein in body and its physiological function is the transportation of steroid hormones (Shahsavani et al., 2010). Also, the importance of albumin has been described in respect to fish pathology, and is widely used as an index of physiological state (Nakagawa, 1978).

During infection white blood cells play a major role by stimulating the immune system and haemopoietic tissues to produce antibodies and chemical mediators which work as defense agent so it considered as a primary line of immunological defense (Tierney et al., 2004). Also, changes in leucocytes occur when fish are stressed and environmental quality is altered (Ponsen et al., 2009). Both innate and adaptive immune response is mounted by fish to control parasite infection (Alvarez-Pellitero, 2008). The innate (non-specific) immune system includes: the phagocytic cells (granulocytes (neutrophil) and monocytes/macrophages) and non-specific cytotoxic cell (Magnadottir, 2006).

In the present study, significantly higher esoinophils count was observed in the infected fishes because of parasitic infestation, where eosinophils were the cells more frequently involved (Alvarez-Pellitero, 2008). An increase in eosinophils count was observed in Clarias batrachus due to helminth infections (Sinha, 2010). Parasitic infection also enhances the phagocytic cells which lead to the clearance of pathogens (Alvarez-Pellitero, 2008), similar reports recorded in this study as there were significant increase in monocyte percent.

The increase or decrease in different types of leucocytes was reported in fish because all leucocytes were calculated as a percentage of the whole leucocytic count which constitutes $100 \%$. The decrease of the percentage of neutrophils in fish groups may be attributed to the significant increase of other leucocytic cells.

\section{CONCLUSION}

Data of this study showed that gill and liver RCs undergo to increase during parasite infection, which could be related to cell activation against parasites. These data also suggest that RCs may play an important role in the non-specific defense mechanisms of teleosts.

\section{REFERENCES}

Abdel-Ghaffar, F.; Bashtar, A.R.; Mehlhorn, H.; Abdel-Gaber, R. and Saleh, R. (2013): Morphological and molecular characterization of Lecithochirium grandiporum (Digenea: Hemiuridae) infecting the European eel Anguilla anguilla as a new host record in Egypt: Parasitol Res 112: 3243-3250.

Abd- Elhafeez, H.H. and Soliman S.A. (2016): Origin of Rodlet Cells and Mapping Their Distribution in Ruby-Red-Fin Shark (Rainbow Shark) Epalzeorhynchos frenatum (Teleostei: Cyprinidae): Light, Immunohistochemistry and Ultrastructure Study: J. Cytol. Histol. 7: 435.

Abdel-Latif, A.M. (2007): Gill parasitic diseases of some freshwater fishes. Ph.D thesis (Fish 
Diseases and Management). Faculty of Veterinary Medicine. Benha University, Egypt.

Agulleiro, B.; Zuasti, A. and Lozano, M.T. (1986): Rodlet cells, gamonts and differentiating microrogamonts of Apicomplexa in teleosts: Acta Microsc 9: 23-30.

Alvarez-Pellitero, P. (2008): Fish immunity and parasite infections: from innate immunity to immunoprophylactic prospects: Veterinary Immunology and Immunopathology 126: 171-198.

Aly, S.; Eissa, I.; Badran, A.; M., E. and Hussain, B. (2005): Pathological Studies on Encysted Metacercariae Infections among some Freshwater Fish in Egyptian Aquaculture. Duetscher Tropentag. Hohenham Univ., Stuttgart, Germany.

Aly, S.; Mayberry, L.; El-Melegy, A. and ElGwady, H. (1995): Pathological studies on parasitic infections in Tilapia nilotica in Egypt: Egyp. J. Comp. Pathol. and Clin. Pathol. 8(2): 147157.

Aly, S; Mayberry, L.; El-Melegy, A. and ElGwady, H. (1995): Pathological studies on parasitic infections in Tilapia nilotica in Egypt. Egyp. J. Comp. Pathol. and Clin. Pathol., Vol. 8 (2) October, 147-157.

Araujo, N.S. and Borges, J.C.S. (2015): Rodlet cells changes in Oreochromis niloticus in response to organophosphate pesticide and their relevance as stress biomarker in teleost fishes: Int. J. Aquat. Biol. 3(6): 398-408.

Austin, B. and Austin, D.A. (2016): Bacterial Fish Pathogens: Disease in Farmed and Wild Fish, 6th ed. Springer International Publishing Switzerland.

Ayanda, O.I. (2009): Comparative parasitic helminth infection between cultured and wild species of Clarias gariepinus in Ilorin, North-Central Nigeria: Scientific Research and Essay 4(1): 18-21.

Bielek, E. (2005): Development of the endoplasmic reticulum in the rodlet cell of two teleost species: Anat. Rec. A Discov. Mol. Cell Evol. Biol. 283: 239-249.

Caruso, G.; Genovese, L.; Maricchiolo, G. and Modica, A. (2005): Haematological, biochemical and immunological parameters as stress indicators in Dicentrarchus labrax and Sparus aurata farmed in off-shore cages: Aquaculture International 13: 67-73.

Chagas, E.C. and Val, A.L. (2003): Effeito da vitmina $\mathrm{C}$ no ganho de peso e em parametros hematologicos de tambaqui: Pesquisa Agropecuaria Brasileira 38(3): 397-402.

Chukwuma, E.R.; Obioma, N. and Christopher, O.I. (2010): The phytochemical composition and some biochemical effects of Nigerian tigernut (Cyperus esculentus L.) tuber: Pakistan Journal of Nutrition 9: 709-715.

Coles, E.H. (1986): Veterinary Clinical Pathology. Philadelphia, Sanders Company. 4th Edition W.B.: 22-23.

Culling, C.F.A.; Allison, R.T. and Barr, W.T. (1985): Cellular pathology tecchnique. Butterworth \& Co. (Publ.). Ltd., London.

Dezfuli, B.S.; Capuano, S. and Manera, M. (1998): A description of rodlet cells from the alimentary canal of Anguilla anguilla and their relationship with parasitic helminths: Journal of Fish Biology 53: 1084-1095.

Dezfuli, B.S.; Giari, L.; Konecny, R.; Jaeger, P. and Manera, M. (2003a): Immunohistochemistry, ultrastructure and pathology of gills of Abramis brama from Lake Mondsee, Austria, infected with Ergasilus sieboldi (Copepoda): Diseases of Aquatic Organisms 53: 257-262.

Dezfuli, B.S.; Giari, L.; Simoni, E.; Bosi, G. and Manera, M. (2002): Histopathology, immunohistochemistry and ultrastructure of the intestine of Leuciscus cephalus naturally infected with Pomphorhynchus laevis (Acanthocephala): Journal of Fish Diseases 25: 7-14.

Dezfuli, B.S.; Giari, L.; Simoni, E.; Palazzi, D. and Manera, M. (2003b): Alteration of rodlet cells in chub caused by the herbicide Stam1 M-4 (Propanil): Journal of Fish Biology 63: 232-239.

Dezfuli, B.S.; Giari, L.; Simoni, E.; Shinn, A.P. and Bosi, G. (2004): Immunohistochemistry, histopathology and ultrastructure of Gasterosteus aculeatus (L.) tissues infected with Glugea anomala (Moniez 1887): Diseases of Aquatic Organisms 58: 193-202.

Dezfuli, B.S.; Simoni, E.; Rossi, R. and Manera, M. (2000): Rodlet cells and other inflammatory cells of Phoxinus phoxinus infected with Raphidascaris acus (Nematoda): Diseases of Aquatic Organisms 43: 61-69.

Eissa, I.A.M.; Gado, M.S.; laila, A.M.; Zaki., M.S. and Noor El-Deen, A.E. (2011): Field Studies Encysted Metacercariae infested Natural Male Tilapias and Monosex Tilapias in Kafr El-Sheikh Governorate Fish Farms: Life Science Journal 8: 7-12.

Fedato, R.P.; Simonato, J.D.; Martinez, C.B.R. and Sofiaa, S.H. (2010): Genetic damage in the bivalve mollusk Corbicula fluminea induced by the water-soluble fraction of gasoline: Mutation Resources 700: 80-85.

Harris, K.K.; Chouhan, K. and Gupta, A.K. (2005): Pathology and histochemistry of Euclinostomum heterostomum Rudolphi, 1925 (Trematoda: Clinostomatidae) metacercarial infection in the snakehead Channa punctatus Bloch, with 
remarks on the chemical nature of the cyst. J Parasit Appl Anim Biol. 14 (1 \& 2): 9-18.

Hawkins, W.E. (1984): Ultrastructure of rodlet cells: response to cadmium damage in the kidney of the spot Leiostomus xanthurus Lacépède: Gulf Res. Reports 7: 365-372.

Hossam, N. et al. (2012): Histopathological studies on the internal parasites of Arabian Mallas Thalasso maklunzengri from red sea. Global J. Fisheries \& Aqa. Res., 5:33-41.

Iger, Y. and Abraham, M. (1997): Rodlet cells in the epidermis of fish exposed to stressors: Tissue \& Cell 29: 431-438.

Imagawa, T.; Kltagawa, H. and Uehara, M. (1998): An association between rodlet cells and the vascular endothelial cells in the head kidney of carp, Cyprinus carpio L.: ultrastructural observation: Journal of Fish Diseases 21: 153-157.

Jones, S.; Prosperi-Porta, G.; Dawe, S., Blackbourn, J.; Taylor, K.; Lowe, G. and Osborn, A. (2004): Proliferative renal myxosporidiosis in spawning Coho salmon (Oncorhynchus kisutch) in British Columbia and Washington: Folia Parasitologica 51: 221-227.

Joshi, P.K.; Bose, M. and Harish, D. (2002): Changes in certain haematological parameters in siluriod catfish, Clarias batrachus (L.) exposed to cadmium chloride: Pollution Resources 21(2): 119-122.

Kharat, S. and Kothawad, S. (2012): Haematological study of Clarias batrachus with reference to trypanosomiasis: Trends in Fisheries Research 1: 6-9.

Kovyrshina, T.B. and Rudneva, I.I. (2012): Comparative study of serum albumin levels in round goby Neogobius melanostomus from Black Sea and Azov Sea: International Journal of Advanced Biological Research 2: 203-208.

Leino, R.L. (2002): The contractile mechanism and "holocrine" secretion in teleost rodlet cells. 53rd Annual Proceeding of the Scandinavian Society for Electron Microscopy, Tampere, Finland

Lied, E.; Czerde, Z. and Braskhan, O.R. (1975): Simple and rapid technique for repeated blood sampling in rainbow trout: J. of Fish Res. Bd. Canada 32(5): 699 -701.

Magnadottir, B. (2006): Innate immunity of fish (overview): Fish and Shellfish Immunology 20: 137-151.

Manera, M. and Dezfuli, B.S. (2004): Rodlet cells in teleosts: a new insight into their nature and functions: Journal of Fish Biology 65: 597619.

Maqsood, S.; Samoon, M.H. and Singh, P. (2009): Immunomodulatory and growth promoting effect of dietary levamisole in Cyprinus carpio fingerlings against the challenge of Aeromonas hydrophila: Turkish Journal of Fisheries and Aquaculture Sciences 9: 111120.

Martone, C.B.; Spivak, E.; Busconi, L.; Folco, E.J. and Sánchez, J.J. (1999): A cysteine protease from myxosporean degrades host myofibrils in vitro: Comparative Biochemistry and Physiology 123: 267-272.

Matisz, C.E; Goater, C.P. and Bray, D. (2010): Density and maturation of rodlet cells in brain tissue of fathead minnows (Pimephales promelas) exposed to trematode cercariae: International Journal for Parasitology 40: 307-312.

Mattey, D.L.; Morgan, M. and Wright, D.E. (1979): Distribution and development of rodlet cells in the gills and pseudobranch of the bass, Dicentrarchus labrax (L): Journal of Fish Biology 15: 363-370.

Mc Manus, J.F.A. (1948): Histological and histochemical uses of periodic acid: Stain Technology 23(3): 99-108.

Mendonca, I.; Matos, E.; Rodrigues, G.; Matos, P.; Casal, G. and Azevedo, C. (2005): Rodlet cells from the gills and kidneys of two Brazilian freshwater fishes: an ultrastructural study: Braz. J. morphol. Sci. 22(4): 187-192.

Morishita, K.; Komiya, Y. and Matsubayshi, $H$. (1965): Metacercariae in Japan and adjacent territories: In Progress of Medical Parasitology in Japan: 1- 335.

Morrison, C.M. and Odense, P.H. (1978): Distribution and morphology of the rodlet cell in fish: Journal of the Fisheries Research Board Canada 35: 101-116.

Nakagawa, H. (1978): Classification of Albumin and Globulin in Yellow tail plasma: Bulletin of the Japanese Society of Scientific Fisheries 44(3): 251-257.

Nandlal, S. and Pickering, T. (2004): Tilapia fish farming in Pacific Island countries. Volume 1. Tilapia hatchery operation. Noumea, New Caledonia: Secretariat of the Pacific Community.

Osman, H.A.M.; Fadel, N.G. and Ali, A.T. (2009): Biochemical and histopathological alterations in catfish, Clarias gariepinus infected with trypanosomiasis with special reference to immunization: Egypt Journal of Comparative Pathology and Clinical Pathology 22: 164181.

Patriche, T.; Patriche, N. and Tenci, M. (2009): Cyprinids total proteins determination: Lucrari Stiintifice Zootechnic Si Biotechnology 42(2): 95-101.

Patriche, T.; Patriche, N.; Bocioc, E. and Coada, M.T. (2011): Serum biochemical parameter of farmed carp (C. carpio): International J. the Bioflux Society 4(2): 131-140. 
Ponsen, S.; Narkkong, N.; Pamok, S. and Aencywanich, W. (2009): Comparative hematological values, morphometric and morphological observation of the blood cell in capture and culture Asian eel (Monopterus albus). American J. Animal and Veterinary Sciences 4(2): 32-36.

Reda, R.M.; El-Nobi, G.A.; Hassanin, M.E.; El Hady, M.A. and El-Bouhy, Z.M. (2010): Study on some encysted Metacercaria "Digenetic Trematodes" Affecting Gills of Oreochromus Niloticus. 10th scientific Veterinary Medicine Zagazig Conference: 518-525.

Reite, O.B. (2005): The rodlet cells of teleostean fish: their potential role in host defence in relation to the mast cells/eosinophilic granule cells: Fish Shellfish Immunol. 19: 253-267.

Reite, O.B. and Evensen, Ø. (2006): Inflammatory cells of teleostean fish: a review focusing on mast cells/eosinophilic granule cells and rodlet cells: Fish \& Shellfish Immunology 20: 192-208.

Shahsavani, D.; Kaxerani, H.; Kaveh, S. and Kanani, H. (2010): Determination of some normal serum parameters in starry Sturgeon (Acipenser stellatus) during spring season: Comp. Clin. Pathol.19: 57-61.

Shoaibi Omrani, B.; Ebrahimzadeh Mousavi, H.A. and Sharif-pour, I. (2010): Occurrence and histopathology of Ascocotyle tenuicollis metacercaria in gill of platyfish (Xiphophorus maculatus) imported to Iran: Iranian Journal of Fisheries Sciences 9: 472-477.

Sinha, K.P. (2010): Haematological manifestation in Clarias batrachus carrying helminth infection: Journal of Parasitic Diseases 24: 167-170.

Smith, S.A.; Caceci, T. and Robertson, J.L. (1995a): Occurrence of rodlet cells and associated lesions in the vascular system of freshwater angelfish: Journal of Aquatic Animal Health 7: 63-69.

Smith, S.A.; Caceci, T.; Marei, H.E.-S. and ElHabback, H.A. (1995b): Observations on rodlet cells found in the vascular system and extravascular space of angelfish (Pterophyllum scalare scalare): Journal of Fish Biology 46: 241-254.
Sohn, W.M. (2009): Fish-borne zoonotic trematode metacercariae in the Republic of Korea: Korean J Parasitol 47 (suppl): S103-S113.

Sohn, W.M. (2013): Invertebrate Founa of Korea Trematodes. Incheon, Korea, The National Institute of Biological Resources. Vol. 6: 1125.

Sommerville, C. (1982): The pathology of Haplorchis pumilio (Looss, 1896) infection in cultured tilapias. J Fish Dis., 5: 243-250. doi: 10.1111/j.1365-2761.1982.tb00479.x.

Soror, E.I.M. (2008): Studies on some internal parasitic diseases of Nile tilapia in Kalubia Governorate. M.Sc. Thesis. Fish diseases and management, Faculty of Veterinary Medicine, Benha University, Egypt:

Stosik, M.; Deptula, W. and Travnicek, M. (2001): Resistance in carp Cyprinus carpio affected by natural bacterial infection: Veterinary Medicine (Czech) 46(1): 6-11.

Syme, J.D. (1966): Fish and fish inspection. 2nd Ed. 52-64. University of Toronto.

Tierney, K.B.; Farrel, A.P. and Kennedy, C.J. (2004): The differential leucocyte landscape of four teleosts: juvenile Oncorhynmchus kisutch, Clupea pallasi, Culapea inconstans and Pimephales promelas. J. Fish Biology, 65: 906-919.

Viehberger, G. and Bielek, E. (1982): Rodlet-cells: Gland cell or protozoon?: Experientia 38: 1216-1218.

Weinreb, E.L. and Bilstad, N.M. (1955): Histology of the digestive tract and adjacent structures of the rainbow trout, Salmo gairdneri irideus: Copeia: 194-204.

Yaji, A.J. and Auta, J. (2007): Sub-lethal effects of monocrotophos on some haematological indices of African catfish Clarias gariepinus (Teugels): Journal of Fisheries International 2(1): 115-117.

Yekutiel, D. (1985): Metacercaria infections of cichlid fry in Lake Kinneret. M.Sc Thesis, Hebrew Universitȳ of Jerusalem (Hebrew text, English summary).

Yemmen, C.; Ktari, M.H. and S., B. (2011): Seasonality and histopathology of Trichodina puytoraci Lom, 1962, a parasite of flathead mullet (Mugil cephalus) from Tunisia: Acta Adriatica 52: 15-20. 


\title{
إستجابة خلايا الرودلت للعدوى بيرقات الديدان المفلطحة فى أسماك البلطي النيلي \\ ولاء فتحى على عميش ، مروه محمد فواز ، زينب الأمجل
}

Email: walaavet2002@yahoo.com Assiut University web-site: www.aun.edu.eg

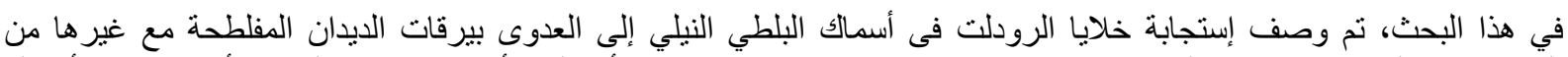

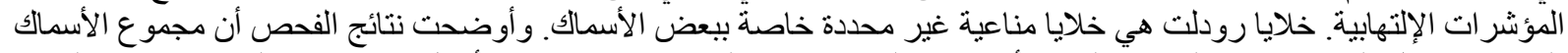

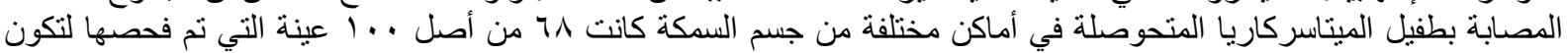

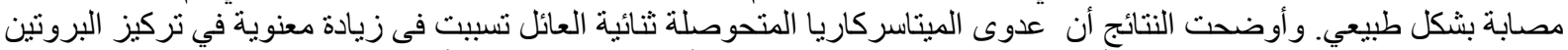

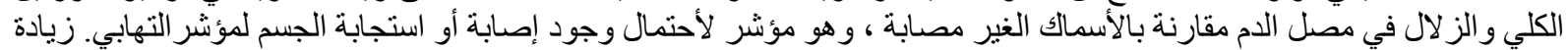

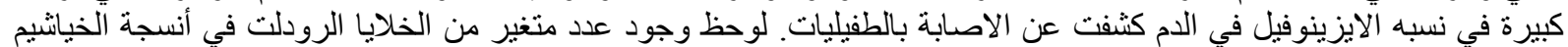

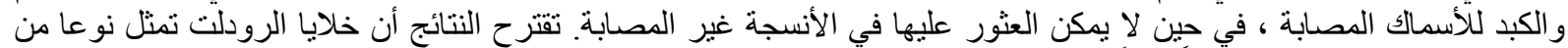

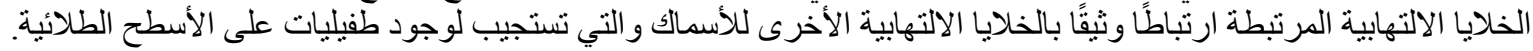

